\title{
Zinc catalyzed Guanylation reaction of Amines with Carbodiimides/ Isocyanate leading to Guanidines/Urea derivatives formation
}

\author{
JAYEETA BHATTACHARJEE, MITALI SACHDEVA, INDRANI BANERJEE and \\ TARUN K PANDA* \\ Department of Chemistry, Indian Institute of Technology Hyderabad, Kandi 502 285, Sangareddy, \\ Telangana, India \\ e-mail: tpanda@iith.ac.in
}

MS received 29 February 2016; revised 16 April 2016; accepted 20 April 2016

\begin{abstract}
We report the highly chemo-selective catalytic addition of $\mathrm{N}-\mathrm{H}$ bonds from various aromatic amines to carbodiimides and isocyanates using (Ar-BIAO) $\mathrm{ZnCl}_{2}$ complexes [Ar-BIAO $=N$-(aryl)iminoacenapthenone, $\mathrm{Ar}=2,6-\mathrm{Me}_{2} \mathrm{C}_{6} \mathrm{H}_{3}(\mathbf{1}), 2,4,6 \mathrm{Me}_{3} \mathrm{C}_{6} \mathrm{H}_{2}(\mathbf{2}), 2,6-{ }^{\mathrm{i}} \mathrm{Pr}_{2} \mathrm{C}_{6} \mathrm{H}_{3}$ (3)] as the pre-catalyst to prepare guanidine and urea derivatives in 55-90\% yield. The complex $\mathbf{3}$ showed higher catalytic activity than analogous complexes $\mathbf{1}$ and $\mathbf{2}$ under similar reaction conditions. The catalytic guanylation of $\mathrm{N}-\mathrm{H}$ bonds with heterocumulenes displays a broad substrate scope. The amines having electron donating groups underwent higher conversion than the amines having electron withdrawing groups to afford corresponding guanidine or urea derivatives. A possible mechanism involving penta-coordinated zinc transition state for the catalytic reaction is presented.
\end{abstract}

Keywords. Carbodiimide; isocyanate; guanidine; urea; Zn catalyst; guanylation.

\section{Introduction}

Guanidine, and the substituted guanidine derivatives are an important class of compounds present in biologically and pharmaceutically active molecules. They have received considerable attention due to their electronic and variable static effects. ${ }^{1}$ Today, Guanidine derivatives are utilized for many purposes as they can serve as building blocks in various pharmaceutical and natural products. $^{2}$ Guanidine derivatives have found extensive applications in medicinal chemistry due to their ability to interact with functional groups present in enzymes or receptors through hydrogen bonds and electrostatic interactions. They are extensively used in medicine as therapeutic agents suitable for the treatment of various diseases and are also involved in antidiabetic, antibacterial, antihistaminic, anti-inflammatory and cardiovascular activity. These molecules can also act as organic bases, and catalyze various organic transformations. ${ }^{3}$ Guanidines are also used as ancillary ligands in the preparation of a variety of metal complexes including those of main group, transition and lanthanide metals. ${ }^{4}$ Many synthetic procedures have been explored for the preparation of guanidines. The most convenient and relevant route is the catalytic addition of amine $\mathrm{N}-\mathrm{H}$ bonds to carbodiimides, also known as guanylation reaction. ${ }^{5-7}$

\footnotetext{
*For correspondence
}

The un-catalyzed guanylation of amines with carbodimides is not a viable process due to requirement of harsh conditions. ${ }^{6 \mathrm{~d}}$ Thus, analyzing various metal catalysts for guanylation reactions has received much interest. Metal complexes such as $\mathrm{LiN}\left(\mathrm{SiMe}_{3}\right)_{2},{ }^{8}$ lanthanide amides and triflets, ${ }^{9}$ titanacarborane amides, ${ }^{10}$ metal alkyls such as half sandwich lanthanide alkyl complex ${ }^{11}$ have been utilized for the synthesis of guanidines. In addition, commercially available alkyl metal complexes $\mathrm{ZnEt}_{2}, \mathrm{MgBu}_{2}$, n-BuLi, and $\mathrm{AlR}_{3}$ have also been explored to be efficient catalysts for this reaction. ${ }^{12}$

Recently, we have reported the synthesis and structural details of various zinc complexes with bi-dentate $N$-(aryl)imino-acenapthenone (Ar-BIAO) ligand, where Ar-BIAO ligand contains conjugated exocyclic carbonyl and imine groups (scheme 1 and figure 1). ${ }^{13}$ We have observed from their molecular structures that a bidentate ligation from the Ar-BIAO ligands occur in each case through lone pairs of nitrogen and oxygen atoms and, by changing the steric crowding on the Ar-BIAO ligand, the nuclearity of the zinc complexes can be changed. In continuation with this project, we found that these zinc complexes are extremely active as pre-catalyst for the guanylation reaction between carbodiimides and amines. Herein we report the reactivity of zinc complexes as pre-catalyst for the reaction of a number of amines with different carbodiimides and isocyanates to synthesize various guanidine and urea derivatives. 


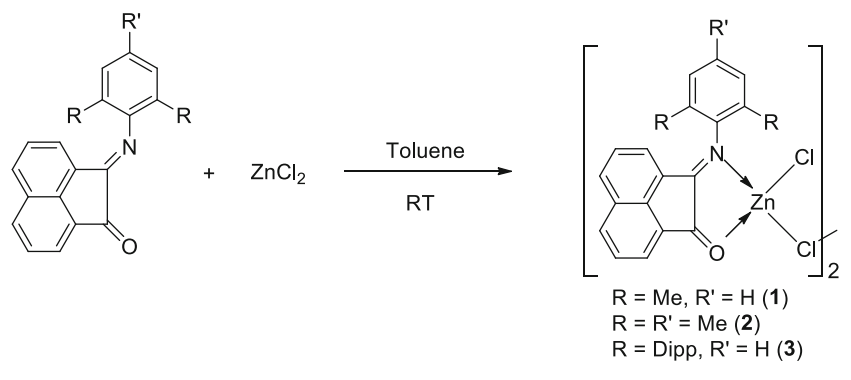

Scheme 1. Synthesis of zinc catalysts $\mathbf{1}-\mathbf{3}{ }^{13}$

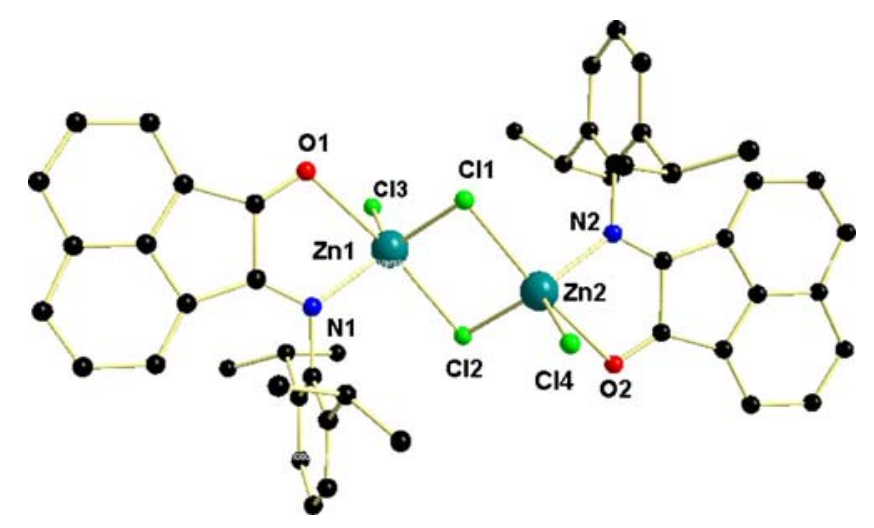

Figure 1. The molecular structure of zinc catalyst $3^{13}$

\section{Experimental}

\subsection{General Information}

All manipulations of air-sensitive materials were performed under inert atmosphere and in flame-dried Schlenk-type glassware, either on a dual manifold Schlenk line interfaced with a high vacuum $\left(10^{-4}\right.$ Torr $)$ line, or in an argon-filled MBRAUN glove box. Hydrocarbon solvents (toluene and $n$-hexane) were distilled under nitrogen from $\mathrm{LiAlH}_{4}$ and stored in the glove box. ${ }^{1} \mathrm{H}$ NMR (400 MHz) and ${ }^{13} \mathrm{C}\left\{{ }^{1} \mathrm{H}\right\}(100 \mathrm{MHz})$, spectra were recorded on a BRUKER AVANCE III-400 spectrometer. All amines, $N, N$ '-di-cyclohexylcarbodiimide, $N, N^{\prime}$-di-tert-butylcarbodiimide and phenylisocyanate were purchased from either Sigma Aldrich or Alfa Aesar. Amines were distilled over $\mathrm{CaH}_{2}$ prior to use. Zinc complexes 1-3 were synthesized according to the published procedure. ${ }^{13} \mathrm{NMR}$ solvent $\left(\mathrm{CDCl}_{3}\right)$ was purchased from Alfa Aesar and distilled over molecular sieves.

2.1a Typical procedure for guanylation reactions: Zinc complex catalyzed guanylation reactions were carried out by using the standard protocol mentioned hereunder. In the glove-box, the chosen pre-catalyst $(0.1 \mathrm{mmol})$ was loaded into a Schlenk tube in $5 \mathrm{~mL}$ toluene, and subsequently, the amine ( $1 \mathrm{mmol}, 1$ equiv) followed by the carbodiimides ( $1 \mathrm{mmol}, 1$ equiv) were added to the Schlenk tube. The mixture was stirred in an oil bath at the desired temperature $\left(90^{\circ} \mathrm{C}\right)$. After $12 \mathrm{~h}$, the solvent was evaporated under vacuum and the residue was dissolved in hexane and kept under stirring for $6 \mathrm{~h}$. The solvent was evaporated to get the white solid product. The yield was calculated from the weight of the compound obtained.

2.1b Characterization of the products A-O (see table 2): The data for $\mathbf{A}$ is already described in the literature. ${ }^{14}$ The ${ }^{1} \mathrm{H}$ and ${ }^{13} \mathrm{C}$ NMR spectral data for guanidine (B-K) and urea derivatives (M-O) are given in the Supporting Information. The ${ }^{1} \mathrm{H}$ and ${ }^{13} \mathrm{C}$ NMR spectra for guanidine and urea derivatives B-O are given in the Supporting Information.

\section{Results and Discussion}

In this study, we describe the catalytic addition of $\mathrm{N}-\mathrm{H}$ bonds from various amines to N,N'- dicyclohexylcarbodiimides and isocyanates with zinc complexes 1-3 as the pre-catalyst. Catalytic experiments were carried out using $10 \mathrm{~mol} \%$ of zinc complex and equimolar amounts of either carbodiimides or isocyanate and amines which were added to a solution of the catalyst with suitable solvent under an inert atmosphere. Initially we employed mesitylamine $\left(2,4,6-\mathrm{Me}_{3} \mathrm{C}_{5} \mathrm{H}_{2} \mathrm{NH}_{2}\right)$ and N,N'-dicyclohexylcarbodiimide (DCC) as model substrates to explore and optimize their catalytic reaction. When 10 mol\% of zinc catalyst 1 was employed as Lewis acid catalyst at $90^{\circ} \mathrm{C}$, we were pleased to find that the desired guanidine product $\mathbf{A}$ was obtained in good yield (table 1, entry 1). Then, other zinc catalysts were examined as Lewis acids in the reaction. The experimental results indicated among these three zinc complexes 1-3, complex 3 exhibited best catalytic activity to the desired guanidine $\mathbf{A}$ in $81 \%$ yield (table 1 , compare entry 3 with entries $1-2$ ). When a zinc bromide complex $2 *\left(\mathrm{MesBIAOZnBr}_{2}\right)^{13}$ was used as precatalyst, only $76 \%$ yield was isolated (table 1 , entry 7 ). We also examined the solvent effect into the reaction and observed that toluene could be the better combination than tetrahydrofuran and dichloromethane (table 1, entries 3-5). It should be noted when only zinc dichloride was used as catalyst, no product was detected (table 1, entry 6). Further raising the temperature from $90^{\circ} \mathrm{C}$ to $110^{\circ} \mathrm{C}$ was not beneficial to the reaction as no increase in yield was observed (table 1, entry 8). The aliphatic amines were not suitable for this catalytic reaction due to their lower boiling points. 
Table 1. Optimization of catalytic reaction between DCC and mesityl amine.

\begin{tabular}{|c|c|c|c|c|c|c|c|}
\hline \multicolumn{2}{|c|}{$\mathrm{Cy}-\mathrm{N}=\mathrm{C}=\mathrm{N}-\mathrm{Cy}$} & \multirow{2}{*}{ Carbodiimide } & \multicolumn{3}{|c|}{$\underset{\text { Solvent, } 12 \mathrm{~h} \text {, heat }}{\stackrel{\text { Zn-Cat. } 10 \mathrm{~mol} \%}{\longrightarrow}}$} & \multicolumn{2}{|r|}{$\overbrace{\mathbf{A}^{\mathrm{N}-}}^{\mathrm{Mes}}$} \\
\hline Entry & Amine & & Catalyst & Solvent & Time (h) & $\mathrm{T}\left({ }^{\circ} \mathrm{C}\right)$ & Yield $(\%)^{a}$ \\
\hline 1 & Mesityl amine & DCC & 1 & Toluene & 12 & 90 & 75 \\
\hline 2 & Mesityl amine & DCC & 2 & Toluene & 12 & 90 & 78 \\
\hline 3 & Mesityl amine & DCC & 3 & Toluene & 12 & 90 & 81 \\
\hline 4 & Mesityl amine & DCC & 3 & THF & 12 & 60 & 70 \\
\hline 5 & Mesityl amine & DCC & 3 & $\mathrm{CH}_{2} \mathrm{Cl}_{2}$ & 12 & 25 & 65 \\
\hline 6 & Mesityl amine & DCC & $\mathrm{ZnCl}_{2}$ & Toluene & 12 & 90 & 0 \\
\hline 7 & Mesityl amine & DCC & $2^{*}$ & Toluene & 12 & 90 & 76 \\
\hline 8 & Mesityl amine & $\mathrm{DCC}$ & 3 & Toluene & 12 & 110 & 81 \\
\hline 9 & Mesityl amine & DCC & - & Toluene & 24 & 90 & 0 \\
\hline
\end{tabular}

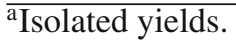

After screening the reaction conditions, it can be concluded that the optimized reaction should be performed using the catalyst of $10 \mathrm{~mol} \%$ complex $\mathbf{3}$ at $90^{\circ} \mathrm{C}$ using toluene as the solvent. The reaction mixture in each case was kept under stirring condition at elevated temperature for $12 \mathrm{~h}$ for carbodiimides and at room temperature for $1 \mathrm{~h}$ in case of isocyanates and the respective guanidine or urea products were isolated. The isolated products were analysed through ${ }^{1} \mathrm{H}$ and ${ }^{13} \mathrm{C} \mathrm{NMR}$ spectroscopy and yields were calculated after isolation of pure products (table 2). Under optimized reaction condition we found that a series of amines had undergone the $\mathrm{N}-\mathrm{H}$ addition reaction smoothly with two different carbodiimides to give corresponding guanidine derivatives in moderate yield. The reaction of unsubstituted aniline with DCC gave 95\% yield (table 2, entry 1). The anilines having nitro group in ortho-, or in para- position were tested for the N-H addition reaction and the yield of $85 \%$ and $75 \%$ of the respective guanidines were observed (table 2, entries 2 and 3 ); however substantial decrease in the yield (53\%) was noticed when $m$-nitroaniline was used as the substrate due to greater extent of deactivating nature of the nitro group at $m$-position of the aniline. However, the aniline moieties were further deactivated when a halide group $(\mathrm{F}, \mathrm{Cl}, \mathrm{I})$ was attached to the phenyl ring as 55$57 \%$ yield of respective urea derivative were obtained (table 2, entries 5-8). The mesityl and 2,6-dimethyl aniline having electron donating effect from the methyl groups were observed to show no significant increase in the yield (table 2, entries 9-10). However, no guanylation product was observed when $\mathrm{DippNH}_{2}$ was used as the amine substrate probably due to enhanced steric hindrance of DippNH $\mathrm{N}_{2}$ which restricted the approach of the bulky carbodiimide (DCC) towards itself (table 2, entry 11). When we reacted N,N'-di-tert-butylcarbodiimide with aniline, we obtained corresponding guanidine in good yield $75 \%$ (entry 12). To extend the scope of the reaction, we treated phenyl isocyanate with tert-butylamine and pyrrolidine under room temperature using the zinc pre-catalyst $\mathbf{3}$. Recently, we have utilized a titanium complex imidazolin-2-iminato titanium amido complexes $\left[\left(\mathrm{Im}^{\text {Dipp }} \mathrm{N}\right) \mathrm{Ti}\left(\mathrm{NMe}_{2}\right)_{3}\right]$ for the catalytic addition of amines with carbodiimide or phenyl isocyanate. ${ }^{15}$ In both the cases, we obtained excellent yield of the corresponding urea derivatives (table 2, entry 13 and 14). However, the DippNH $\mathrm{H}_{2}$ gave slightly reduced yield of the respective urea due to bulky size of the aniline moiety (table 2 , entry 15). Thus we observed that, zinc pre-catalyst $\mathbf{3}$ can smoothly catalyse the guanylation reaction of a number of anilines with DCC at a slightly elevated temperature; however the reaction with phenyl isocyanate with amines required room temperature only.

A possible mechanism for zinc complex $\mathbf{3}$ catalyzed guanylation of amines to carbodiimides is proposed in scheme 2. In the first step, carbodiimido nitrogen should react with zinc complex $\mathbf{3}$ which is a Lewis acid catalyst through the lone pair of nitrogen to generate pentacoordinated zinc intermediate $\mathbf{I}$ where zinc can bear the negative charge and the second nitrogen of the carbodimido moiety bears positive charge. The nucleophilic addition of an amine to I would afford another pentacoordinated zinc intermediate II. Finally, intramolecular proton transfer of II readily led to regenerate pre-catalyst $\mathbf{3}$ and release the free guanidine. Similar mechanistic cycles are known in literature. ${ }^{16}$ 
Table 2. Catalytic formation of guanidine and urea derivatives using $\mathbf{3}$ as pre-catalyst ${ }^{\mathrm{a}}$.
Cat. 3(10 mol\%)
(a) $\mathrm{R}^{\prime}-\mathrm{N}=\mathrm{C}=\mathrm{N}-\mathrm{R}^{\prime}+\mathrm{RNH}_{2}$
$\underset{12 \mathrm{~h}, 90^{\circ} \mathrm{C}}{\stackrel{\text { Toluene }}{\longrightarrow}}$
$\mathrm{H}_{\mathrm{H}^{\prime}}^{\mathrm{NHR}}$
$\stackrel{1,3 \text { shift }}{\longrightarrow} \mathrm{R}^{\prime} \mathrm{N}_{\mathrm{H}_{\mathrm{H}}}^{\mathrm{NR}}$
$\mathrm{R}^{\prime}=\mathrm{Cy}$ or $t \mathrm{Bu}$
(b) $\mathrm{Ph}_{\mathrm{N}=\mathrm{C}=\mathrm{O}}+\mathrm{RNH}_{2} \stackrel{\text { Toluene }}{1 \mathrm{~h}, \mathrm{RT}} \rightarrow$

Entry Amine
2<smiles>Nc1ccc([N+](=O)[O-])cc1</smiles>
$\mathrm{CyN}=\mathrm{C}=\mathrm{NCy}$
Product
(B)
95
3<smiles>Nc1ccccc1[N+](=O)[O-]</smiles>
$\mathrm{CyN}=\mathrm{C}=\mathrm{NCy}$<smiles>Cc1ccc([N+](=O)[O-])cc1</smiles>
Yield $(\%)^{\mathrm{b}}$
4<smiles>Nc1cccc([N+](=O)[O-])c1</smiles>
$\mathrm{CyN}=\mathrm{C}=\mathrm{NCy}$<smiles>CN=C(NC1CCCCC1)NC1CCCCC1</smiles>
(C)
85<smiles>O=[N+]([O-])c1ccccc1N=C(NC1CCCCC1)NC1CCCCC1</smiles>
75<smiles>O=[N+]([O-])c1cccc(N=C(NC2CCCCC2)NC2CCCCC2)c1</smiles>
Cy
$\mathrm{CyN}=\mathrm{C}=\mathrm{NCy}$
(E)
5<smiles>Nc1ccccc1F</smiles>
$\mathrm{CyN}=\mathrm{C}=\mathrm{NCy}$<smiles>Fc1ccccc1N=C(NC1CCCCC1)NC1CCCCC1</smiles>
(F)<smiles>ClN/C(=N\c1ccccc1Cl)NC1CCCCC1</smiles>
6<smiles>Nc1ccccc1Cl</smiles>
$\mathrm{CyN}=\mathrm{C}=\mathrm{NCy}$<smiles>Ic1ccccc1N=C(NC1CCCCC1)NC1CCCCC1</smiles>
G)<smiles>Nc1ccccc1I</smiles> 
Table 2. Continue.

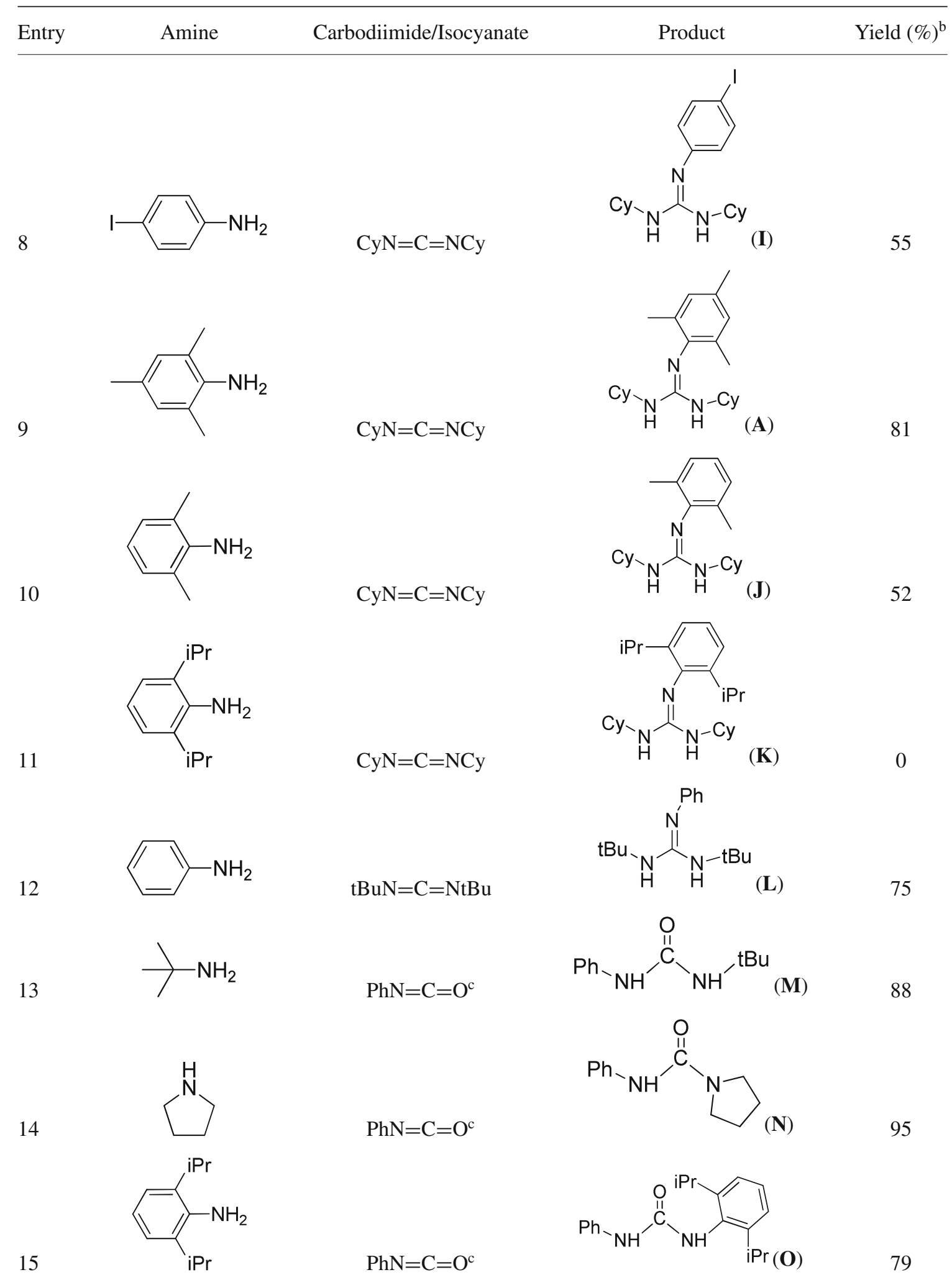

${ }^{\mathrm{a}} \mathrm{All}$ compounds were characterized by ${ }^{1} \mathrm{H}$ and ${ }^{13} \mathrm{C}$ NMR spectroscopy using $\mathrm{CDCl}_{3}$ as $\mathrm{NMR}$ solvent. ${ }^{\mathrm{b}}$ Yields were calculated from isolated pure products. ${ }^{\mathrm{c}}$ Room temperature. 


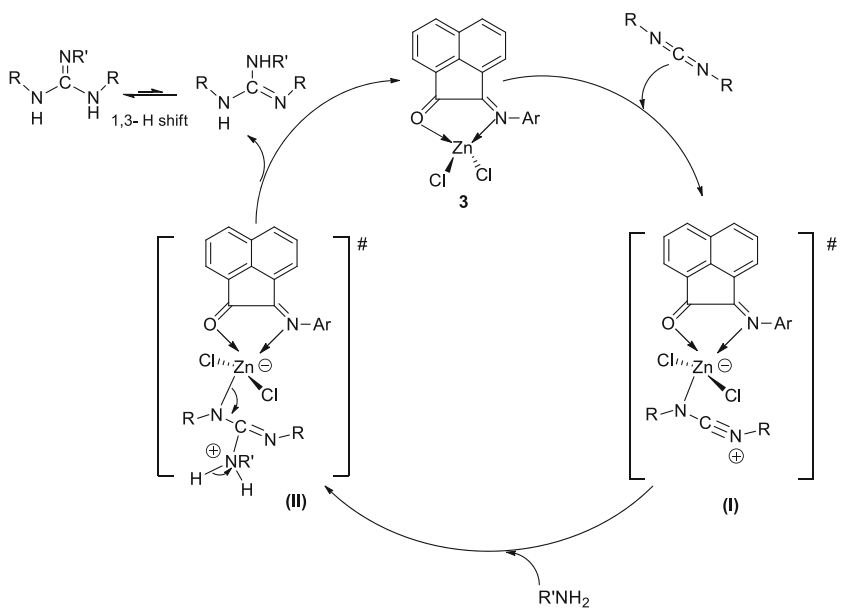

Scheme 2. Most plausible mechanism for the catalytic addition of $\mathrm{N}-\mathrm{H}$ bond to carbodiimide using zinc precatalyst $\mathbf{3}$.

\section{Conclusions}

In summary, we have presented the highly chemoselective catalytic addition of $\mathrm{N}-\mathrm{H}$ bonds from various aromatic amines to carbodiimides and isocyanate using a zinc pre-catalyst supported by $N$-(aryl)iminoacenapthenone ligand. The zinc complex $\mathbf{3}$ was proved to be efficient pre-catalyst for the conversion of aromatic amines to the corresponding guanidines via guanylation reaction with carbodiimides at elevated temperature in 55-95\% yield. Complex 3 was also a potent catalyst for the conversion of isocyanate to corresponding urea in excellent yield when amines were reacted with isocyanate at room temperature. A possible mechanism involving five coordinated zinc intermediate is proposed for the guanylation reaction.

\section{Supplementary Information (SI)}

The ${ }^{1} \mathrm{H}$ and ${ }^{13} \mathrm{C}$ NMR spectral data for guanidine (B$\mathbf{K})$ and urea derivatives (M-O) are given in the Supporting Information. The ${ }^{1} \mathrm{H}$ and ${ }^{13} \mathrm{C}$ NMR spectra for guanidine and urea derivatives B-P are given in the Supporting Information, available at www.ias.ac.in/ chemsci.

\section{Acknowledgements}

This work was supported by Science and Engineering Research Board (SERB), Department of Science and Technology (DST), India under project no. (SB/S1/IC/045/2013). The instrumental facilities were provided by the Indian Institute of Technology Hyderabad (IITH). J. B. thanks UGC, India for her PhD fellowship.

\section{References}

1. (a) Durant G J 1985 Chem. Soc. Rev. 14 375; (b) Berlinck R G S 1996 Nat. Prod. Rep. 13 377; (c) Berlinck R G S 1999 Nat. Prod. Rep. 16 339; (d) Heys L, Moore C G and Murphy P J 2000 Chem. Soc. Rev. 29 57; (e) Berlinck R G S 2002 Nat. Prod. Rep. 19617

2. (a) Berlinck R G S, Burtoloso A C B and Kossuga M H 2008 Nat. Prod. Rep. 25 919; (b) Castagnolo D and Schenone S Botta 2011 M. Chem. Rev. 111 5247; (c) Berlinck R G S, Trindade-Silva A E and Santos M F C 2012 Nat. Prod. Rep. 29 1382; (c) Schmuck C 2006 Coord. Chem. Rev. 250 3053; (d) Berlinck R G S, Burtoloso A C B, Trindade-Silva A E, Romminger S, Morais R P, Bandeira K and Mizuno C M 2010 Nat. Prod. Rep. 27 1871; (e) Berlinck R G S 1996 Nat. Prod. Rep. 13377

3. (a) Ishikawa $\mathrm{T}$ and Kumamoto $\mathrm{T} 2006$ Synthesis 737; (b) Ishikawa T 2010 Chem. Pharm. Bull. 58 1555; (c) Taylor J E, Bull S D and Williams J M 2012 J. Chem. Soc. Rev. 41 2109; (d) Coles M P 2009 Chem. Commun. 3659

4. (a) Barker J and Kilner M 1994 Coord. Chem. Rev. 133 219; (b) Bailey P J and Pace S 2001 Coord. Chem. Rev. 214 91; (c) Coles M P 2006 Dalton Trans. 985; (d) Edelmann F T 2009 Chem. Soc. Rev. 38 2253; (e) Edelmann F T 2008 Adv. Organomet. Chem. 57 183; (f) Rowley C N, Di Labio G A and Barry S T 2005 Inorg. Chem. 44 1983; (g) Foley S R, Zhou Y, Yap G P A and Richeson D S 2000 Inorg. Chem. 39 924; (h) Dagorne S, Guzei I A, Coles M P and Jordan R F $2000 \mathrm{~J}$. Am. Chem. Soc. 122 274; (i) Coles M P, Swenson D C and Jordan R F 1998 Organometallics 17 4042; (j) Milanov A P, Thiede T B, Devi A and Fischer R A $2009 \mathrm{~J}$. Am. Chem. Soc. 131 17062; (k) Ong T G, Yap G P A and Richeson D S 2003 J. Am. Chem. Soc. 125 8100; (1) Rohde J U and Lee W T 2009 J. Am. Chem. Soc. 131 9162; (m) Shen H, Chan H S and Xie Z 2007 J. Am. Chem. Soc. 12912934

5. (a) Ong T G, O'Brien J S, Korobkov I and Richeson D S 2006 Organometallics 25 4728; (b) Shen H, Chan H and Xie Z 2006 Organometallics 25 5515; (c) Li J Zhang and Z Fan E 2004 Tetrahedron Lett. 45 1267; (d) Wu Y Q, Hamilton S K, Wilkinson D E and Hamilton G S 2002 J. Org. Chem. 67 7553; (e) Evindar G and Batey R A 2003 Org. Lett. 5 133; (f) Powell D A, Ramsden P D and Batey R A 2003 J. Org. Chem. 68 2300; (g) Linton B R, Carr A J, Orner B P and Hamilton A D 2000 J. Org. Chem. 65 1566; (h) Tin M K T, Thirupathi N, Yap G P A and Richeson D S 1999 Dalton Trans. 17 2947; (i) Feichtinger K, Zapf C, Sings H L and Goodman M 1998 J. Org. Chem. 633804

6. (a) Tin M K T, Yap G P A and Richeson D S 1998 Inorg. Chem. 37 6728; (b) Molina P, Alajarín M, SanchezAndrada P, Sanz-Aparicio J and Martínez-Ripoll M 1998 J. Org. Chem. 63 2922; (c) Chinchilla R, Najera C and Sanchez Agullo P 1994 Tetrahedron: Asymmetry 5 1393; (d) Bernatowicz M S, Wu Y and Matsueda G R 1992 J. Org. Chem. 572497

7. For general reviews on guanylating agents, see: (a) Katritzky A R and Rogovoy B V 2005 ARKIVOC 4 49; (b) Suhs T and Konig B 2006 Mini Rev. Org. Chem. 3 315 
8. (a) Ong T-G, O'Brien J S, Korobkov I and Richeson D S 2006 Organometallics 254728

9. (a) Li Q, Wang, S, Zhou S, Yang G, Zhu X and Liu Y 2007 J. Org. Chem. 72 6763; (b) Zho S, Wang S, Yang G, Li Q, Zhang, L, Yao Z, Zhou Z and Song H 2007 Organometallics 26 3755; (c) Du Z, Li W, Zhu X, Xu F and Shen Q 2008 J. Org. Chem. 73 8966; (d) Zhu X, X F Shen and Q Chin 2009 J. Org. Chem. 27 19; (e) Zhu X, Du Z, Xu F and Shen Q 2009 J. Org. Chem. 74 6347; (f) Wu Y, Wang S, Zhang L, Yang G, Zhu X, Liu C, Yin C and Rong J 2009 Inorg. Chim. Acta 362 2814; (g) Zhang X, Wang C, Qian C, Han F, Xua F and Shen Q 2011 Tetrahedron 678790

10. Shen H, Chan H-S and Xie Z 2006 Organometallics 25 5515

11. (a) Zhang W, Nishiura M and Hou Z 2007 Chem. Eur. J. 13 4037; (b) Zhang W, Nishiura M and Hou Z 2006 Synlett 1213

12. (a) Alonso-Moreno C, Carrillo-Hermosilla F, Garces A, Otero A, Lopez-Solera I, Rodriguez A M and Antinolo A
2010 Organometallics 29 2789; (b) Li D, Guang J, Zhang W-X, Wang Y and Xi Z 2010 Org. Biomol. Chem. 8 1816; (c) Zhang W-X, Li D, Wang Z and Xi Z 2009 Organometallics 28 882; (d) Koller J and Bergman R G 2010 Organometallics 295946

13. (a) Anga S, Pal T, Kottalanka R K, Paul M and Panda T K 2013 Can. Chem. Trans. 1 105; (b) Anga S, Rej S, Naktode K, Pal T and Panda T K 2015 J. Chem. Sci. 127103

14. F Montilla, A Pastor and A Galindo 2004 J. Org. Chem. 689993

15. (a) Naktode K, Das S, Bhattacharjee J, Nayek H P and Panda T K 2016 Inorg. Chem. 5531142

16. (a) Kantam M L, Priyadarshini S, Joseph P J A, Srinivas P, Vinu A, Klabunde K J and Nishina Y 2012 Tetrahedron 68 5730; (b) Kantam M L, Dupati V, Vallabha S J and Monorama S V 2013 J. Chem. Sci. 125 1339; (c) Zhu X, Du Z, Xu F and Shen Q 2009 J. Org. Chem. 746347 